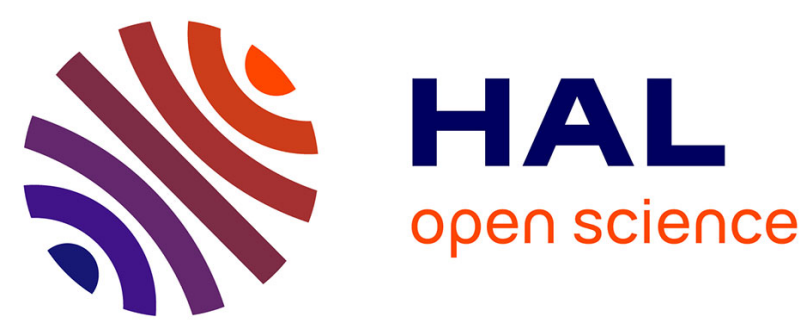

\title{
Flow regime assessment in falling film evaporators using residence time distribution functions
}

\author{
Arlan Caldas Pereira Silveira, Gaëlle Tanguy-Sai, I. Tuler Perrone, Romain \\ Jeantet, Fabrice Ducept, Antonio Fernandes de Carvahlo, Pierre Schuck
}

\section{- To cite this version:}

Arlan Caldas Pereira Silveira, Gaëlle Tanguy-Sai, I. Tuler Perrone, Romain Jeantet, Fabrice Ducept, et al.. Flow regime assessment in falling film evaporators using residence time distribution functions. Journal of Food Engineering, 2015, 160, pp.65-76. 10.1016/j.jfoodeng.2015.03.016 . hal-01173930

\author{
HAL Id: hal-01173930 \\ https://hal.science/hal-01173930
}

Submitted on 27 May 2020

HAL is a multi-disciplinary open access archive for the deposit and dissemination of scientific research documents, whether they are published or not. The documents may come from teaching and research institutions in France or abroad, or from public or private research centers.
L'archive ouverte pluridisciplinaire HAL, est destinée au dépôt et à la diffusion de documents scientifiques de niveau recherche, publiés ou non, émanant des établissements d'enseignement et de recherche français ou étrangers, des laboratoires publics ou privés. 


\title{
Flow regime assessment in falling film evaporators using residence time distribution functions
}

\author{
Arlan Caldas Pereira Silveira ${ }^{\mathrm{a}, \mathrm{b}, \mathrm{c}, \mathrm{d}}$, Gaëlle Tanguy ${ }^{\mathrm{a}, \mathrm{b}}$, Ítalo Tuler Perrone ${ }^{\mathrm{d}}$, Romain Jeantet ${ }^{\mathrm{b}, \mathrm{a}}$, \\ Fabrice Ducept ${ }^{\mathrm{e}}$, Antônio Fernandes de Carvalho ${ }^{\mathrm{d}}$, Pierre Schuck ${ }^{\mathrm{a}, \mathrm{b}, *}$ \\ a INRA, UMR1253, F-35000 Rennes, France \\ ${ }^{\mathrm{b}}$ Agrocampus Ouest, UMR1253, F-35000 Rennes, France \\ ${ }^{\mathrm{C}}$ Scholarship Student by CNPq, Brazil \\ ${ }^{\mathrm{d}}$ Universidade Federal de Viçosa, 36350-000 Viçosa, Brazil \\ e AgroParisTech, INRA, UMR1145, F-91744 Massy, France
}

\section{A R T I C L E I N F O}

\section{Article history:}

Received 21 November 2014

Received in revised form 5 March 2015

Accepted 12 March 2015

Available online 27 March 2015

\section{Keywords:}

Falling film evaporators

Skim milk

Residence time distribution

Flow regime

\begin{abstract}
A B S T R A C T
A falling film evaporator (FFE) is an industrial device to concentrate solutions. The aim of this study was to identify the flow regime, and characterize and model the residence time distribution (RTD) functions of a FFE. Experimental runs were carried out with skim milk at three different feed mass flow rates. Flow was characterized using experimental Reynolds number $\left(R e_{\mathrm{f}}\right)$. The RTD function in the FFE was measured in four sections of the vacuum evaporator equipment. These RTD functions were modeled by a combination of perfectly mixed reactor tanks in series. In this study, when the flow regime changed from wavylaminar to laminar, the mean residence time increased. The flow was analyzed as a main and a minor retarded flow, where two layers of product flowed through the evaporation tubes. The future of this work consists of extending the RTD approach to other products and operating conditions in the evaporator device.
\end{abstract}

(c) 2015 Elsevier Ltd. All rights reserved.

\section{Introduction}

Concentration by vacuum evaporation is used to decrease the volume and weight of the product, which subsequently reduces the cost of packaging, storage and transport and facilitates the conservation of the concentrate by lowering the water activity (Bouman et al., 1993; Prost et al., 2006; Bimbenet et al., 2007). This process is used for the production of final (sweetened condensed milk, evaporated milk, etc.) (Gänzle et al., 2008), and intermediate products before any further operations such as crystallization, precipitation, coagulation or drying (infant formulae, whey and milk powders, etc.) (Schuck, 2002; Bimbenet et al., 2007; Zhu et al., 2011).

Falling film evaporators (FFE) are widely used in the chemical and food industries for their ability to process heat-sensitive products. The evaporator device is called "falling film" because the liquid falls in a trickling film along the inner wall of the tube. This type of device allows higher heat transfer coefficients, therefore lower residence times can be achieved in comparison with other

* Corresponding author at: INRA, UMR1253, F-35000 Rennes, France. Tel.: +33 (0)2 23485322 (Std); fax: +33 (0)2 23485350 .

E-mail address: pierre.schuck@rennes.inra.fr (P. Schuck). designs of evaporator (Bimbenet et al., 2007). However, industrial control of this process often relies on an empirical understanding of the phenomena involved, which then results in a time and cost consuming development phase to establish optimal operating conditions when the final product quality must be changed or a new type of product processed.

As boiling and concentration occur simultaneously inside the FFE, the study of the mechanisms is complex (Li et al., 2011; Pehlivan and Ozdemir, 2012); indeed, the rates of enzymatic and chemical changes depend on solute concentration, product temperature and time, and it is therefore necessary to take into account these three parameters in order to control thermal damage of constituents and process-dependent properties (product physicochemical properties and product end-properties).

Moreover, the few scientific papers available on the topic of vacuum evaporation in food and chemical domains mainly focus on the calculation and optimization of the heat transfer coefficient (Chun and Seban, 1971; Mafart, 1991; Jebson and Iyer, 1991; Bouman et al., 1993; Chun and Park, 1995; Jebson and Chen, 1997; Silveira et al., 2013), and there is a lack of research and information concerning the characterization of the flow regime and of the residence time distribution (RTD) functions of the product, $E(t)$, during concentration in FFE. Moreover, RTD is a powerful 


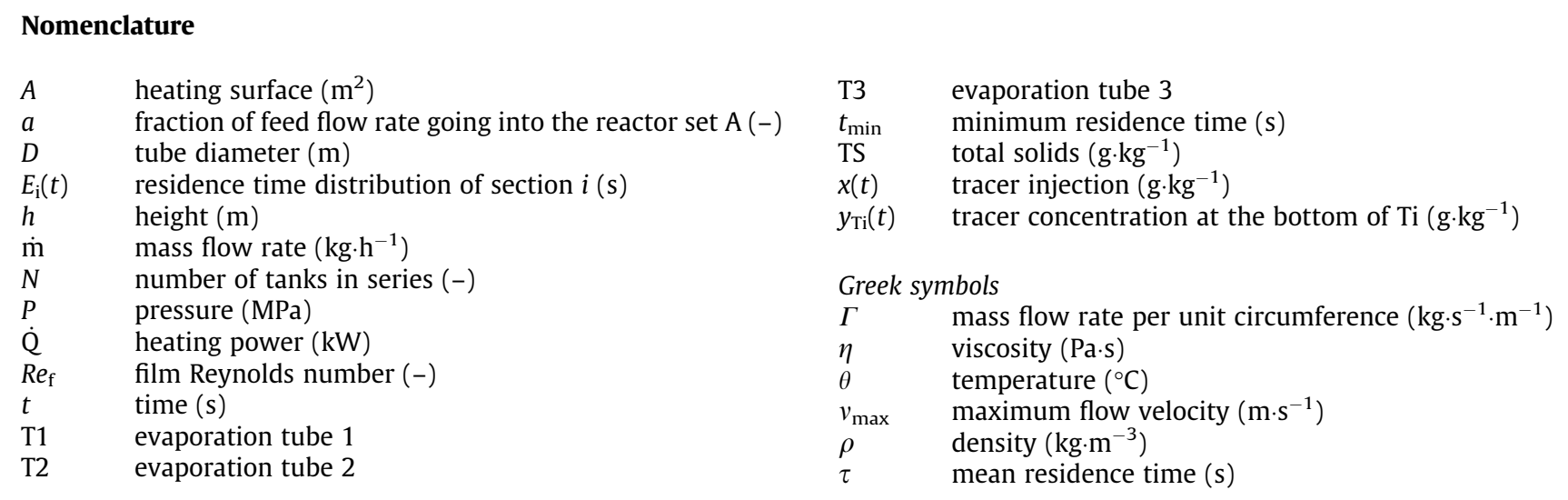

approach to characterizing the mixing phenomena and flow regime in chemical reactor systems, which allows comparison with ideal reactors.

Determination of the product RTD is an overall and experimental approach which provides valuable information about the product flow regime in the evaporator, according to the operational conditions. It does not provide a good physical understanding of the operation as computational fluid dynamics does but, on the other hand, it integrates the product and process complexity fully.

Computational fluid dynamics (CFD) allow study of the consequences of modifications in operating conditions (temperature, flow rate) and process configuration with regard to particle characteristics (temperature, water content) and trajectories in the dryer (Ducept et al., 2002; Verdurmen et al., 2002). Nevertheless a numerical simulation of a real evaporator process is not accessible in practice: complex geometry (evaporation tubes, pipelines, pumps, etc.), presence of water and vapor, pressure alterations, etc. The experimental CFD is too complex, and hardly representative of the evaporation process. The experimental RTD allows, in a relatively simple way, to have valuable information about the product and process complexity fully.

Since the pioneering work of Danckwerts (1953), the RTD theory has been widely developed, and is nowadays used in a more general context in order to determine a population balance model (Villermaux, 1982), where the basis of this model is that the number of entities with certain properties in a system is a balanceable quantity. Such properties include size, mass, and age. RTD theory is also used to optimize the process in terms of capital and operation costs (Malcata, 1991). The latter represent an essential step to managing and controlling the quality of food products. Burton et al. (1959) applied the concept of RTD to food engineering in order to calculate the sterilizing effectiveness of an UHT apparatus for milk processing. Baloh (1979) showed that the loss of sugar in pasteurization and evaporation processes of various processing schemes in the sugar industry could be significantly lowered by reducing the mean residence time of sweet juice. Thor and Loncin (1978) established the mechanisms of rinsing (e.g. mass flow rate and shear stress) of a plate heat exchanger by the measurement of RTD and thereby laid down the basis for optimizing rinsing equipment in food engineering. Jeantet et al. (2008) calculated and modeled the RTD for different sections of a spray-drying tower for skim milk and described the intensity of the heat treatment that the product was subjected to during this process.

No studies have been published on the characterization and modeling of RTD in falling film evaporators for concentration of food products. Understanding both RTD and kinetics of product temperature along its flow in the equipment should pave the way for further prediction of chemical changes (e.g. protein denaturation) that occur during this processing step. The aim of this study was first to characterize RTD functions of a pilot falling film evaporator experimentally, and then to model these RTD functions and identify the flow regime of the process.

\section{Materials and methods}

\subsection{Pilot vacuum evaporator}

The equipment used in these experiments consisted of a pilot scale, single stage falling-film evaporator (GEA Process Engineering, St Quentin-en-Yvelines, France; Fig. 1). This equipment, described in Silveira et al. (2013), has three evaporation tubes in series. The inner diameter of the first tube (T1) is greater than those of the second and third tubes (T2, T3), which have the same diameter (Table 1).

Each tube has an independent electrical heating system (b in Fig. 1) that provides the vaporization energy. As the vapor emitted by the product (secondary vapor) is not used for heating the product in the next tube, this pilot is a single stage evaporator. The secondary vapor is condensed in the condenser (a in Fig. 1), and eliminated ( 7 in Fig. 1 ) by the condensate extraction pumps.

The experiments were performed at a total heating power of $25.20 \pm 0.05 \mathrm{~kW}$ (Table 1$)$. The heating power $(8.40 \pm 0.02 \mathrm{~kW}$ for each tube) was controlled by measuring the current and the voltage with a clamp meter and a voltmeter (Fluke Co Ltd, Everett, USA) respectively.

All experiments were performed at an absolute pressure $\left(P_{\mathrm{abs}}\right)$ of $0.02 \mathrm{MPa}$, and thus the saturation temperature of evaporation was maintained at $60^{\circ} \mathrm{C}$ throughout the three tubes.

The evaporator is equipped with probes to record the temperatures of the product and the secondary vapor in each tube (points $3_{\mathrm{T} 1}, 3_{\mathrm{T} 2}$, and $3_{\mathrm{T} 3}-$ Fig. 1). Feed product, concentrate and condensate flow rates were measured with flow meters at different points (points 1, 5, and 7 - Fig. 1), and conductivity with conductivity meters (points $4_{\mathrm{T} 1}, 4_{\mathrm{T} 2}$ and $4_{\mathrm{T} 3}$ - Fig. 1) placed at the bottom of each tube.

\subsection{Experimental runs}

Experimental runs were carried out with skim milk at three different feed mass flow rates $\left(60 \mathrm{~kg} \cdot \mathrm{h}^{-1}, 70 \mathrm{~kg} \cdot \mathrm{h}^{-1}\right.$ and $\left.80 \mathrm{~kg} \cdot \mathrm{h}^{-1}\right)$.

Skim milk was recombined at $100 \mathrm{~g} \cdot \mathrm{kg}^{-1}$ of total solids (TS) from skim milk powder (Lactalis ingredients, Bourgbarré, France). It was heated at $60{ }^{\circ} \mathrm{C}$ before entering the evaporator. After passing 


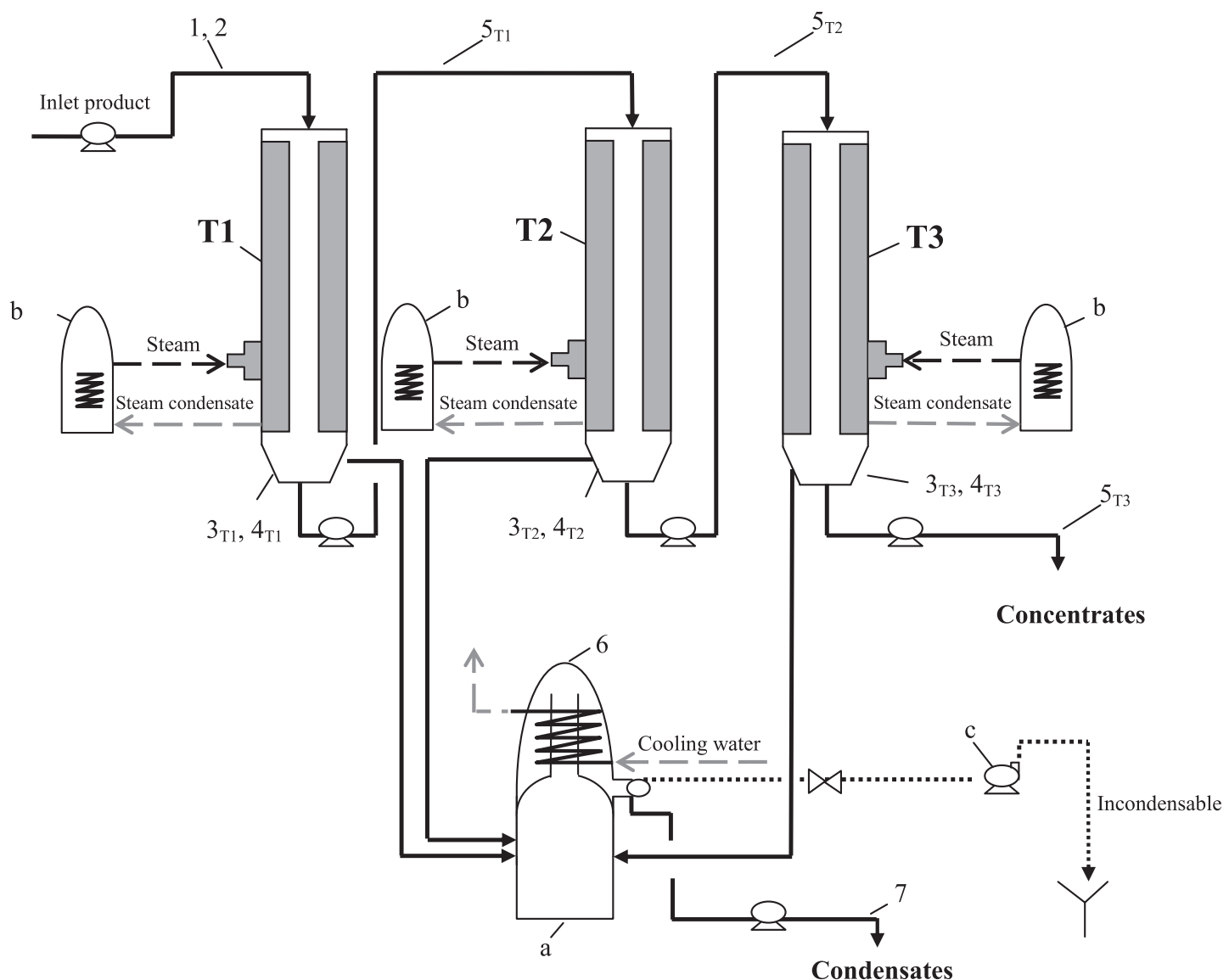

1 - Inlet mass flow rate of product

2 - Inlet product temperature

3 - Temperature of product

4 - Conductivity of product concentrate

5 - Mass flow rate of product concentrate

6 - Temperature of condenser

7 - Outlet mass flow rate of product condensate a - Separator and indirect condenser

b - Boilers

c - Vacuum pump

Fig. 1. Single-effect falling-film evaporator. $1 \rightarrow 7$ : measurement parameters, a $\rightarrow$ c: equipment components.

Table 1

Operating and design parameters of the three tubes in the FFE. Wall thickness of each tube is $1 \mathrm{~mm}$.

\begin{tabular}{lllll}
\hline Tube No. & $D(\mathrm{~m})$ & $h(\mathrm{~m})$ & $A\left(\mathrm{~m}^{2}\right)$ & $Q(\mathrm{~kW})$ \\
\hline 1 & 0.036 & 4.0 & 0.45 & 8.4 \\
2 & 0.023 & 4.0 & 0.29 & 8.4 \\
3 & 0.023 & 4.0 & 0.29 & 8.4 \\
Total & & & 1.03 & 25.2
\end{tabular}

$D=$ diameter; $h=$ height; $A$ = heating surface; $Q=$ heating power.

through the three evaporation tubes (Fig. 1) (first run - 1R), the product (still at $60^{\circ} \mathrm{C}$ ) was reintroduced into the equipment and re-concentrated a second time, again passing through the three evaporation tubes (second run - 2R). This operation was performed once more time (third run - 3R). The inlet and outlet TS of skim milk concentrates at the bottom of the three evaporations tubes for the three feed mass flow rates and runs studied are shown in Table 2.

The conductivity of skim milk concentrates exceeding $520 \mathrm{~g} \cdot \mathrm{kg}^{-1}$ of TS could not be measured reliably due to their high viscosity. Therefore, for the feed mass flow rate of $60 \mathrm{~kg} \cdot \mathrm{h}^{-1}$, the TS of the product exiting the second run at $389 \mathrm{~g} \cdot \mathrm{kg}^{-1}$ (Table 2) were diluted to $283 \mathrm{~g} \cdot \mathrm{kg}^{-1}$ of TS and re-introduced into the evaporator for the third run. This dilution was undertaken to limit the concentration to $520 \mathrm{~g} \cdot \mathrm{kg}^{-1}$ of TS at the end of the third run.

In total, 27 experiments were performed, at three feed mass flow rates and in three runs. The experimental conditions are summarized in Table 2.

\subsection{Total solids}

The feed and final total solids content (TS) were calculated according to weight loss after drying $5 \mathrm{~g}$ of each sample with sand in a forced air oven at $105^{\circ} \mathrm{C}$ for $7 \mathrm{~h}$.

The TS of the product at the bottom of the first and second tube were calculated as:

$\mathrm{TS}_{\mathrm{i}}=\frac{\dot{\mathrm{m}}_{\mathrm{in}_{\mathrm{i}}} \cdot \mathrm{TS}_{\mathrm{in}_{\mathrm{i}}}}{\dot{\mathrm{m}}_{\mathrm{out}_{\mathrm{i}}}}$

where $\dot{\mathrm{m}}_{\mathrm{in}_{\mathrm{i}}}$ is the inlet mass flow rate of the product in tube $i, \mathrm{TS}_{\mathrm{in}_{\mathrm{i}}}$ corresponding to the TS of the inlet product in the bottom of tube $i$, and $\dot{\mathrm{m}}_{\text {out }_{\mathrm{i}}}$ corresponding to the outlet mass flow rate of the product in tube $i$. 
Table 2

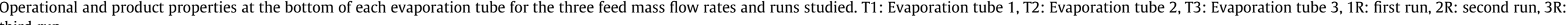
third run.

\begin{tabular}{|c|c|c|c|c|c|c|c|c|c|c|}
\hline \multirow{2}{*}{$\begin{array}{l}\text { Feed mass flow rate } \\
\text { Evaporation tubes }\end{array}$} & & \multicolumn{3}{|c|}{$80 \mathrm{~kg} \cdot \mathrm{h}^{-1}$} & \multicolumn{3}{|c|}{$70 \mathrm{~kg} \cdot \mathrm{h}^{-1}$} & \multicolumn{3}{|c|}{$60 \mathrm{~kg} \cdot \mathrm{h}^{-1}$} \\
\hline & & $\mathrm{T} 1$ & $\mathrm{~T} 2$ & $\mathrm{~T} 3$ & $\mathrm{~T} 1$ & T2 & T3 & $\mathrm{T} 1$ & T2 & T3 \\
\hline $1 \mathrm{R}$ & $\begin{array}{l}\Gamma\left(\mathrm{kg} \cdot \mathrm{s}^{-1} \cdot \mathrm{m}^{-1}\right) \\
\mathrm{TS}\left(\mathrm{g} \cdot \mathrm{kg}^{-1}\right) \\
\rho\left(\mathrm{kg} \cdot \mathrm{m}^{-3}\right) \\
\eta_{100}\left(10^{-3} \mathrm{~Pa} \cdot \mathrm{s}\right) \\
\operatorname{Re}_{\mathrm{f}}\end{array}$ & $\begin{array}{l}0.170 \pm 0.000 \\
108 \pm 1 \\
1024 \pm 0.5 \\
0.7 \pm 0.1 \\
971\end{array}$ & $\begin{array}{l}0.235 \pm 0.000 \\
123 \pm 4 \\
1031 \pm 0.6 \\
1.0 \pm 0.1 \\
940\end{array}$ & $\begin{array}{l}0.199 \pm 0.001 \\
145 \pm 2 \\
1040 \pm 0.7 \\
1.0 \pm 0.1 \\
796\end{array}$ & $\begin{array}{l}0.156 \pm 0.001 \\
114 \pm 2 \\
1027 \pm 1.0 \\
0.7 \pm 0.1 \\
891\end{array}$ & $\begin{array}{l}0.211 \pm 0.001 \\
133 \pm 4 \\
1035 \pm 1.1 \\
1.0 \pm 0.1 \\
844\end{array}$ & $\begin{array}{l}0.177 \pm 0.000 \\
161 \pm 2 \\
1047 \pm 0.5 \\
1.1 \pm 0.1 \\
643\end{array}$ & $\begin{array}{l}0.125 \pm 0.000 \\
123 \pm 2 \\
1031 \pm 0.8 \\
0.9 \pm 0.0 \\
555\end{array}$ & $\begin{array}{l}0.162 \pm 0.001 \\
149 \pm 5 \\
1042 \pm 2.2 \\
1.0 \pm 0.0 \\
648\end{array}$ & $\begin{array}{l}0,127 \pm 0.001 \\
195 \pm 3 \\
1062 \pm 1.5 \\
1.6 \pm 0.1 \\
317\end{array}$ \\
\hline $2 \mathrm{R}$ & $\begin{array}{l}\Gamma\left(\mathrm{kg} \cdot \mathrm{s}^{-1} \cdot \mathrm{m}^{-1}\right) \\
\mathrm{TS}\left(\mathrm{g} \cdot \mathrm{kg}^{-1}\right) \\
\rho\left(\mathrm{kg} \cdot \mathrm{m}^{-3}\right) \\
\eta_{100}\left(10^{-3} \mathrm{~Pa} \cdot \mathrm{s}\right) \\
\operatorname{Re}_{\mathrm{f}}\end{array}$ & $\begin{array}{l}0.171 \pm 0.000 \\
165 \pm 3 \\
1049 \pm 0.8 \\
1.2 \pm 0.0 \\
570\end{array}$ & $\begin{array}{l}0.238 \pm 0.001 \\
187 \pm 4 \\
1058 \pm 1.7 \\
1.5 \pm 0.0 \\
635\end{array}$ & $\begin{array}{l}0.199 \pm 0.001 \\
240 \pm 3 \\
1081 \pm 0.5 \\
2.6 \pm 0.1 \\
306\end{array}$ & $\begin{array}{l}0.158 \pm 0.001 \\
188 \pm 4 \\
1059 \pm 1.8 \\
1.5 \pm 0.0 \\
421\end{array}$ & $\begin{array}{l}0.213 \pm 0.000 \\
221 \pm 5 \\
1073 \pm 2.1 \\
2.1 \pm 0.0 \\
406\end{array}$ & $\begin{array}{l}0.181 \pm 0.001 \\
264 \pm 1 \\
1091 \pm 0.9 \\
3.4 \pm 0.1 \\
213\end{array}$ & $\begin{array}{l}0.127 \pm 0.000 \\
234 \pm 4 \\
1078 \pm 1.5 \\
2.5 \pm 0.0 \\
203\end{array}$ & $\begin{array}{l}0.163 \pm 0.001 \\
290 \pm 1 \\
1103 \pm 1.4 \\
4.4 \pm 0.0 \\
148\end{array}$ & $\begin{array}{l}0.130 \pm 0.000 \\
389 \pm 5 \\
1145 \pm 2.1 \\
12.3 \pm 0.1 \\
42\end{array}$ \\
\hline $3 \mathrm{R}$ & $\begin{array}{l}\Gamma\left(\mathrm{kg} \cdot \mathrm{s}^{-1} \cdot \mathrm{m}^{-1}\right) \\
\mathrm{TS}\left(\mathrm{g} \cdot \mathrm{kg}^{-1}\right) \\
\rho\left(\mathrm{kg} \cdot \mathrm{m}^{-3}\right) \\
\eta_{100}\left(10^{-3} \mathrm{~Pa} \cdot \mathrm{s}\right) \\
\operatorname{Re}_{\mathrm{f}}\end{array}$ & $\begin{array}{l}0.177 \pm 0.001 \\
254 \pm 2 \\
1087 \pm 0.9 \\
3.0 \pm 0.1 \\
236\end{array}$ & $\begin{array}{l}0.240 \pm 0.000 \\
298 \pm 3 \\
1106 \pm 1.5 \\
4.8 \pm 0.0 \\
200\end{array}$ & $\begin{array}{l}0.206 \pm 0.000 \\
350 \pm 1 \\
1128 \pm 2.3 \\
5.9 \pm 0.1 \\
139\end{array}$ & $\begin{array}{l}0.163 \pm 0.000 \\
305 \pm 4 \\
1109 \pm 1.1 \\
5.2 \pm 0.1 \\
125\end{array}$ & $\begin{array}{l}0.219 \pm 0.000 \\
365 \pm 5 \\
1135 \pm 0.9 \\
9.6 \pm 0.0 \\
91\end{array}$ & $\begin{array}{l}0.189 \pm 0.001 \\
434 \pm 6 \\
1164 \pm 1.6 \\
33.0 \pm 0.1 \\
23\end{array}$ & $\begin{array}{l}0.128 \pm 0.001 \\
331 \pm 1 \\
1120 \pm 1.8 \\
6.7 \pm 0.1 \\
76\end{array}$ & $\begin{array}{l}0.165 \pm 0.000 \\
417 \pm 2 \\
1157 \pm 1.6 \\
16.5 \pm 0.0 \\
40\end{array}$ & $\begin{array}{l}0.138 \pm 0.001 \\
516 \pm 4 \\
1200 \pm 0.7 \\
68.3 \pm 0.1 \\
8\end{array}$ \\
\hline
\end{tabular}

$\Gamma=$ mass flow rate per unit circumference; TS = total solids; $\rho=$ density; $\eta_{100}=$ apparent viscosity at $100 \mathrm{~s}^{-1} ; R e_{\mathrm{f}}=$ film Reynolds number. 


\subsection{Viscosity measurement}

Viscosity measurements were obtained at $60^{\circ} \mathrm{C}$ with a Physica MCR 301 rheometer (Anton Paar, Graz, Austria) using a coaxial aluminum cylinder (inner radius $23.05 \mathrm{~mm}$; outer radius $25 \mathrm{~mm}$; height of rotor $30 \mathrm{~mm}$; gap $5 \mathrm{~mm}$ ). Shear rates between $10 \mathrm{~s}^{-1}$ and $1000 \mathrm{~s}^{-1}$ at $60^{\circ} \mathrm{C}$, were used for rheological determinations. As skim milk behaves as a non-Newtonian fluid at higher concentrations, apparent viscosity at a shear rate of $100 \mathrm{~s}^{-1}\left(\eta_{100}\right)$ was used to make comparisons between the different products. This shear rate value was chosen because it is representative of the value reached in agitation, flow in tubes and other industrial operations (Steffe, 1996). The viscosity of the product was measured immediately after taking the samples at the bottom of the evaporator tubes.

\subsection{Density measurements}

A Mettler-Toledo densimeter DE40 (Mettler-Toledo, Columbus, USA) was used to determine the density of the products at $60^{\circ} \mathrm{C}$.

\subsection{Conductivity}

The conductivity of the product was measured every second (after tracer injection) at the bottom of the three tubes (points $4_{\mathrm{T} 1}, 4_{\mathrm{T} 2}$ and $4_{\mathrm{T} 3}-$ Fig. 1 ) by conductivity-meter (Endress Hauser SAS, Huningue, France). The conductivity was measured in an indirect way to determine the concentration of the tracer. Calibration curves were established to take into account the intrinsic conductivity of the product, which changes according to the skim milk concentration (Sharifi and Young, 2012), and to estimate the concentration of the tracer.

\subsection{Characterization of the flow}

For falling films, the flow regimes are usually characterized by the degree of turbulence in the liquid phase, and a significant dimensionless number used for characterizing the flow is the Reynolds number of the film $\left(R e_{\mathrm{f}}\right)$. It measures the importance of inertia relative to viscous effects and is defined for falling films as follows:

$\operatorname{Re}_{\mathrm{f}}=\frac{4 \Gamma}{\eta}$

where $\Gamma$ is the mass flow rate per unit circumference of the tube $\left(\mathrm{kg} \cdot \mathrm{m}^{-1} \cdot \mathrm{s}^{-1}\right)$ and $\eta$ the apparent viscosity of the product $(\mathrm{Pa} \cdot \mathrm{s})$, both measured at the bottom of the tubes.

$\Gamma$ was measured according to Eq. (3):

$\Gamma=\frac{\dot{\mathrm{m}}}{\pi \mathrm{D}}$

where $\dot{m}$ is the concentrate mass flow rate measured and $D$ is the inner diameter of the tube.

Flow was characterized using an experimental Reynolds number, and the classification defined by Bird et al. (1960) that established the flow regimes for the falling film in three regions was used:

- $R e_{\mathrm{f}}<25$ : laminar flow;

- $25<R e_{\mathrm{f}}<1000$ : laminar flow with waves (wavy-laminar);

- $R e_{\mathrm{f}}>1000$ : turbulent flow.

As $R e_{\mathrm{f}}$ was always measured at the bottom of the evaporation tubes, the characterization of the flow behavior in sections 3 and 4 was always the same, as both were measured at the bottom of T3.
The maximum flow velocity, corresponding to the velocity of the first fluid elements that arrived at the bottom of the evaporation tube, was calculated according Eq. (4).

$v_{\max }=\frac{\text { length of a section }}{\mathrm{t}_{\mathrm{i}_{\min }}}$

where $v_{\max }$ is the maximum flow velocity and $\mathrm{t}_{\mathrm{i}_{\min }}$ the time that the first particles of tracer take to arrive at the bottom of tube . $_{\text {. }}$

\subsection{Measurement of residence time distribution}

RTD are determined experimentally by injecting an inert chemical, molecule or atom, called a tracer, into a reactor at some time, $t=0$, and then measuring the tracer concentration in the effluent stream as a function of time. In this study, RTD characterization was based on the follow-up of the concentration of sodium chloride added to the product, according to Jeantet et al. (2008). Therefore the time that the sodium chloride molecules and the product fluid elements took in the evaporator equipment was considered to be the same.

As the pilot operates as a continuous process, the products with and without the tracer were put in two different tanks connected to the feed line with a three-way valve, which allowed rapid change in the nature of the feed product. Using this technique the shape of the injection signal could be considered to be square. The product with $10 \mathrm{~g} \cdot \mathrm{kg}^{-1}$ of sodium chloride was injected into the evaporator for $30 \mathrm{~s}$ (Fig. 2).

The outlet sodium chloride concentration, measured indirectly by conductivity, was calculated at the bottom of the three evaporation tubes. It was then possible to plot the sodium chloride concentrations in the effluent stream as a function of time, $\left(y_{\mathrm{i}}(t)\right)$ (Fig. 2).

The RTD signal $\left(E_{\mathrm{i}}(t)\right)$ was measured in four different sections of the vacuum evaporator (Fig. 3) with MATLAB and Statistics Toolbox Release (2014b, The MathWorks, Inc., Natick, Massachusetts, United States). 1 corresponds to the section from the feed to the bottom of the first tube; 2 the section from the bottom of the first tube to the bottom of the second tube; 3 the section from the bottom of the second tube to the bottom of the third tube; and 4 the section from the feed to the outlet of the evaporator.

$E_{1}(t)$ was calculated by numerical deconvolution of $\mathrm{y}_{\mathrm{T}_{1}}(\mathrm{t})$ with the injection signal $(x(t))$. The sodium chloride concentration measured at the bottom of $\mathrm{T} 1\left(y_{\mathrm{T} 1}(t)\right)$ was the injection signal for calculating $E_{\mathbf{2}}(t) . E_{2}(t)$ was therefore calculated by numerical deconvolution of $y_{\mathrm{T} 2}(t)$ with $y_{\mathrm{T} 1}(t)$. For $E_{3}(t)$ the injection signal

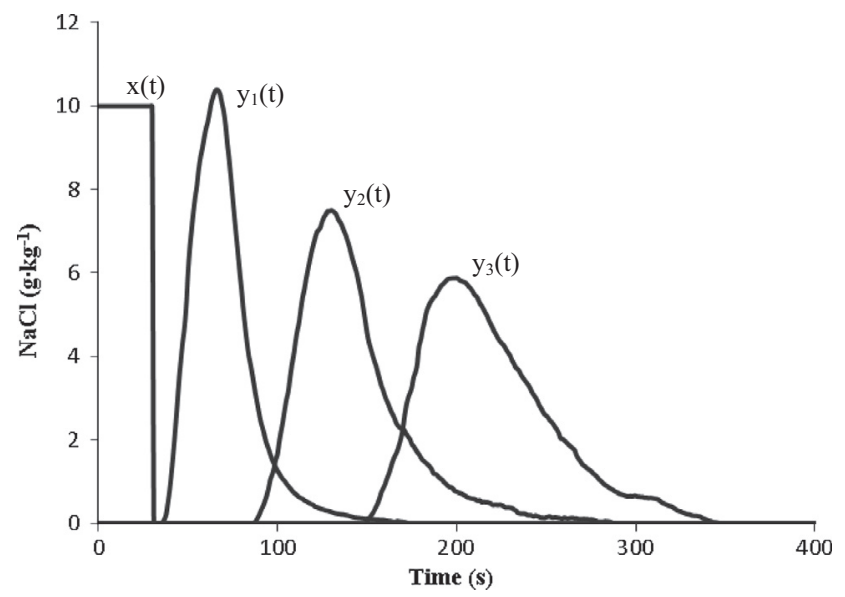

Fig. 2. Tracer injection $x(t)$ and output signal at bottom of $\mathrm{T} 1\left(y_{1}(t)\right), \mathrm{T} 2\left(y_{2}(t)\right)$ and T3 $\left(y_{3}(t)\right)$. Measurements at feed mass flow rate of $70 \mathrm{~kg} \cdot \mathrm{h}^{-1}$ at $3 \mathrm{R}$. 
was $y_{\mathrm{T} 2}(t)$, and thus $E_{3}(t)$ was calculated by numerical deconvolution of $y_{\mathrm{T} 2}(t)$ with $y_{\mathrm{T} 3}(t)$ (Eqs. (5)-(7)). The overall RTD from the inlet to the outlet of the evaporator $\left(E_{4}(t)\right)$ was calculated by numerical deconvolution of $y_{\mathrm{T} 3}(t)$ by the injection signal $(x(t))$ (Eq. (8)).

$y_{\mathrm{T} 1}(t)=x(t) \otimes E_{1}(t)$

$y_{\mathrm{T} 2}(t)=y_{\mathrm{T} 1}(t) \otimes E_{2}(t)$

$y_{\mathrm{T} 3}(t)=y_{\mathrm{T} 2}(t) \otimes E_{3}(t)$

$y_{\mathrm{T} 3}(t)=x(t) \otimes E_{4}(t)$

Having determined $E_{\mathrm{i}}(t)$ for the different sections of the vacuum evaporator, it was then possible to determine the residence time of each fluid element, and, conversely, the time at which a certain fraction of the material entering at $t=0$ was no longer present in the equipment. The mean residence time, $\tau$, corresponds to the time when $50 \%$ of the material entering at $t=0$ passed through the equipment.

The RTD functions for the four different sections of the FFE were modeled by a set of perfectly mixed reactor tanks in series in order to take into account the flow regime in the evaporator. Each reactor set includes $N_{\mathrm{i}}$ reactor tanks in series, and can be characterized by a mean residence time $\left(\tau_{\mathrm{i}}\right)$. Its own RTD function is defined by:

$E_{\mathrm{i}}(t)=\left(\frac{N_{\mathrm{i}}}{\tau_{i}}\right)^{N_{\mathrm{i}}} \cdot \frac{t_{i}^{N_{i}-1} \cdot \exp \left(N_{i} \cdot t_{i} / \tau_{i}\right)}{\left(N_{i}-1\right) !}$

The number of tanks in series, $N_{\mathrm{i}}$, provides information about the dispersion of the fluid elements: a high $N$ value indicates small dispersion of the particles in the reactor (Gutierrez et al., 2010).

For modeling the RTD of the four different sections (Fig. 3), it was considered that the product passed through two reactor sets, A and B (Fig. 4), characterized by two RTD functions $E_{\mathrm{a}}(t)$ and $E_{\mathrm{b}}(t)$. Reactor set $\mathrm{C}$, is a combination of these two reactor sets. It is characterized by the function $E_{\mathrm{c}}(t)$, which describes the experimental RTD of FFE (Fig. 4) (Eq. (10)).

$$
E_{\mathrm{c}}(t)=(1-a) \cdot E_{\mathrm{b}}(\mathrm{t})+\mathrm{a} \cdot E_{\mathrm{a}}(t)
$$

where $a$ refers to the fraction of feed flow rate going into reactor set A. The three parameters of each reactor set $\left(a_{\mathrm{i}}, \tau_{\mathrm{i}}\right.$ and $\left.N_{\mathrm{i}}\right)$ were adjusted in order to fit the modeled curve to the experimental curve. A manual trial and error methodology was used to fix the optimal values of model parameters instead of a classical algorithm minimizing the sum of squared error between predicted and measured values.

Model accuracy was evaluated by calculation of the standard deviation between the model and experimental RTD curves.

\section{Results and discussion}

\subsection{Product and flow characterization}

Although the mass flow rate of product was higher in T1 compared to the other two tubes, the value of $\Gamma$ at the bottom of T1 was always lower than those at the bottom of T2 and T3 for the same feed flow rate because of a higher inner diameter $(0.036 \mathrm{~m}$ for T1 instead of $0.023 \mathrm{~m}$ for T2 and T3 (Table 1)). As tubes T2 and T3 had the same diameter, $\Gamma$ at these points depended only on the mass flow rate of the product (Eq. (3)). Due to evaporation, the mass flow rate of the product at the bottom of T2 was always higher than that at the bottom of T3: $\Gamma_{\mathrm{T} 2}>\Gamma_{\mathrm{T} 3}$. For the experiments conducted at $80 \mathrm{~kg} \cdot \mathrm{h}^{-1}$, when the concentration of the product increased from $108 \mathrm{~g} \cdot \mathrm{kg}^{-1}$ to $254 \mathrm{~g} \cdot \mathrm{kg}^{-1}$ of TS at the bottom of $\mathrm{T} 1 / 1 \mathrm{R}$ and $\mathrm{T} 1 / 3 \mathrm{R}$, respectively (Table 2 ), the $\Gamma$ increased from $0.170 \mathrm{~kg} \cdot \mathrm{s}^{-1} \cdot \mathrm{m}^{-1}$ to $0.177 \mathrm{~kg} \cdot \mathrm{s}^{-1} \cdot \mathrm{m}^{-1}$, evidencing an increase in the product flow rate, since the tube diameter was constant. Compared to other tubes and runs, the increase in the product concentration caused an increase in the $\Gamma$, and therefore a decrease in the evaporation rate, as the concentrate mass flow rate increased.

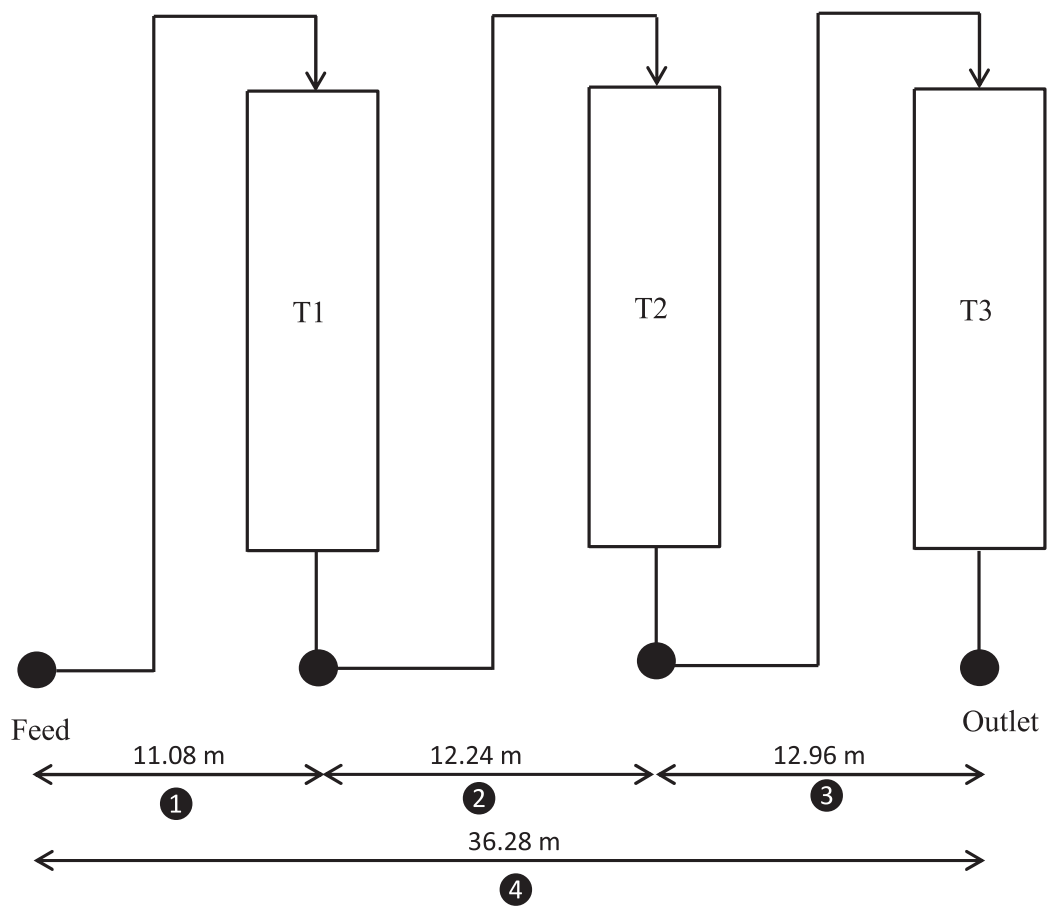

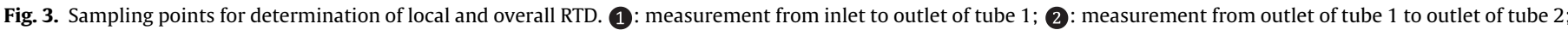
3 measurement from outlet of tube 2 to outlet of tube 3; 4: overall RTD measurement from inlet to outlet of the falling film evaporator. 


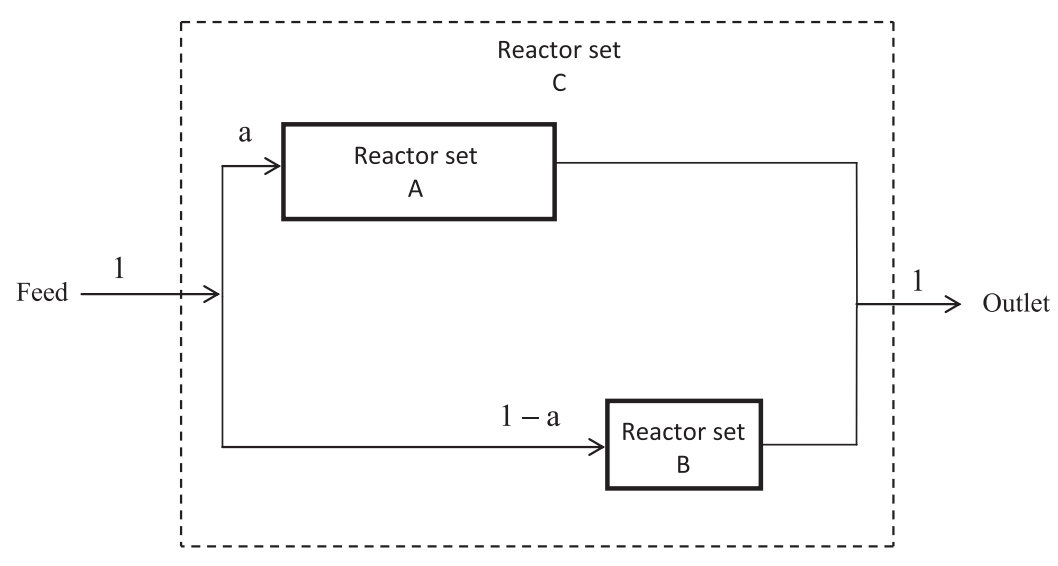

Fig. 4. Reactor tank sets in series used for modeling the RTD of FFE for the four sections studied.

These results are in agreement with those of Morison and Broome (2014).

The concentration of the product at the bottom of the three evaporation tubes for the three feed mass flow rates and runs studied is shown in Table 2 . At $80 \mathrm{~kg} \cdot \mathrm{h}^{-1}$ the skim milk concentration at the end of the third run of the evaporation process was $350 \mathrm{~g} \cdot \mathrm{kg}^{-1}$ compared to $434 \mathrm{~g} \cdot \mathrm{kg}^{-1}$ and $516 \mathrm{~g} \cdot \mathrm{kg}^{-1}$ at feed mass flow rates of $70 \mathrm{~kg} \cdot \mathrm{h}^{-1}$ and $60 \mathrm{~kg} \cdot \mathrm{h}^{-1}$, respectively. As the evaporation parameters, and in particular the heating power, were kept constant (except for the feed mass flow rate) the energy transferred to the product was the same, and therefore the concentration of the product at the bottom of the evaporator tubes increased according to the decrease in feed mass flow rate.

Density increased proportionately with TS of the skim milk concentrates, whereas viscosity increased exponentially from approximately $365 \mathrm{~g} \cdot \mathrm{kg}^{-1}$ of TS, which is consistent with the results of Chong et al. (2009). The apparent viscosity, $\eta_{100}$, of skim milk concentrate at $516 \mathrm{~g} \cdot \mathrm{kg}^{-1}$ of TS was $68.3 \cdot 10^{-3} \mathrm{~Pa} \cdot \mathrm{s}$. This value, that was higher than that found by Silveira et al. (2013), might be explained by the time that the product remained at $60^{\circ} \mathrm{C}$ before measurements. Indeed at higher concentration, the viscosity of the milk concentrate increased with time, a phenomenon known as age thickening (Westergaard, 2004). Thus the residence time of the product during concentration in the FFE may affect the viscosity of the concentrate (Baldwin et al., 1980). Viscosity is an important parameter to be monitored for optimal atomization in a spraydryer (Schuck, 2002; Westergaard, 2004).

The values of $R e_{\mathrm{f}}$ are shown in Table $2 . R e_{\mathrm{f}}$ varied between 971 and 8 , points corresponding to the maximum and minimum flow rates and product concentration at $80 \mathrm{~kg} \cdot \mathrm{h}^{-1}$ at bottom of T1/R1 and at $60 \mathrm{~kg} \cdot \mathrm{h}^{-1}$ at the bottom of T3/3R. In this study, $R e_{\mathrm{f}}$ decreased as the product passed through the evaporation tubes, decreasing its flow rate and increasing its viscosity. These two factors thus led to a lower $\operatorname{Re}_{\mathrm{f}}$ at the bottom of the third tube compared to the first and second tubes for the same feed mass flow rate.

The flow regimes at the bottom of the evaporation tubes are presented in Table 3. Almost all products presented a wavy laminar profile, except T3/3R at $70 \mathrm{~kg} \cdot \mathrm{h}^{-1}$ and $60 \mathrm{~kg} \cdot \mathrm{h}^{-1}$ for which a laminar flow was deduced from $R e_{\mathrm{f}}$.

\section{2. $R T D$ characterization}

To improve understanding of the path of the skim milk fluid elements in the evaporator, and thereby improve the characterization of the flow in the FFE, the residence time distribution (RTD) function was maintained. The RTD curves in the third run at a feed mass flow rate of $70 \mathrm{~kg} \cdot \mathrm{h}^{-1}$ are presented in Fig. 5. All curves had the same surface area. The experimental RTD curves at $80 \mathrm{~kg} \cdot \mathrm{h}^{-1}$ and $60 \mathrm{~kg} \cdot \mathrm{h}^{-1}$ presented similar shapes. For all feed mass flow rates and runs studied, a more highly concentrated product led to a lower peak on the curves and greater dispersion of the fluid elements.

The times that the first fluid elements took to arrive at the bottom of the evaporation tubes $\left(t_{\min }\right)$ after tracer injection are shown in Table 3 for the different sections studied. $t_{\min }$ was the same for each section and feed mass flow rate, wherever the run. Only the feed flow rate and the distance covered by the product in the evaporator influenced this parameter. The distance covered by the product of section 3 was greater than section 2 , which in turn was greater than section (1). Section 4 represented the sum of the other three (Fig. 3).

The maximum flow velocity, $v_{\max }$, defined as the ratio of the length of a section over $t_{\mathrm{min}}$, and measured at the bottom of the tubes, is shown in Table 3. $v_{\max }$ was $0.33 \pm 0.01 \mathrm{~m} \cdot \mathrm{s}^{-1}$, $0.31 \pm 0.00 \mathrm{~m} \cdot \mathrm{s}^{-1}$ and $0.26 \pm 0.01 \mathrm{~m} \cdot \mathrm{s}^{-1}$, for T1 in the experiments conducted at $80 \mathrm{~kg} \cdot \mathrm{h}^{-1}, 70 \mathrm{~kg} \cdot \mathrm{h}^{-1}$ and $60 \mathrm{~kg} \cdot \mathrm{h}^{-1}$, respectively. $v_{\max }$ was $0.31 \pm 0.00 \mathrm{~m} \cdot \mathrm{s}^{-1}, \quad 0.23 \pm 0.00 \mathrm{~m} \cdot \mathrm{s}^{-1}, \quad 0.22 \pm 0.00 \mathrm{~m} \cdot \mathrm{s}^{-1}$ at $70 \mathrm{~kg} \cdot \mathrm{h}^{-1}$ for T1, T2 and T3, respectively, and $v_{\max }$ of Section 4 represented approximately the mean maximum velocity $\left(0.25 \mathrm{~m} \mathrm{~s}^{-1}\right)$ of the three sections. In this study, $v_{\max }$ decreased as the product passed through the evaporation tubes. This was mainly due to the reduction in the mass flow rate and increase in viscosity, due to product evaporation.

The mean residence time, $\tau$, for a given section was the same for experiments conducted at a feed mass flow rate of $80 \mathrm{~kg} \cdot \mathrm{h}^{-1}$. At $70 \mathrm{~kg} \cdot \mathrm{h}^{-1}$ and $60 \mathrm{~kg} \cdot \mathrm{h}^{-1}$, $\tau$ was higher in R3 for Sections 3 and 4. The increase in $\tau$ was assumed to be associated with a higher viscosity of the product, which in turn, is a key parameter for determining the flow regime. Higher liquid film dispersion contributed to a higher mean residence time of the product. When the flow regime changed from wavy-laminar to laminar flow, $\tau$ was increased. For the experiments conducted in this study, the laminar flow regime has a mean residence time above that of wavy-laminar flow, hence the lower mean velocity.

As previously discussed, the evaporation rate decreases with product concentration, possibly due to a decrease in the heat transfer coefficient, a change in flow regime, a boiling delay phenomenon (i.e. product having a high boiling point due to greater concentration of solutes), etc. When the evaporation rate decreased, the mass flow rate of the product concentrate decreased less compared to high evaporation rate, which also increased the flow velocity and therefore decreased the residence time of the 
Table 3

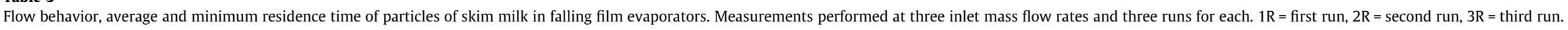

\begin{tabular}{|c|c|c|c|c|c|c|c|c|c|c|c|c|c|}
\hline \multirow{2}{*}{$\begin{array}{l}\text { Feed mass flow rate } \\
\text { Section (Fig. 2) }\end{array}$} & & \multicolumn{4}{|c|}{$80 \mathrm{~kg} \cdot \mathrm{h}^{-1}$} & \multicolumn{4}{|c|}{$70 \mathrm{~kg} \cdot \mathrm{h}^{-1}$} & \multicolumn{4}{|c|}{$60 \mathrm{~kg} \cdot \mathrm{h}^{-1}$} \\
\hline & & (1) & 2 & (3) & 4 & (1) & 2 & 3 & 4 & (1) & 2 & 3 & 4 \\
\hline $1 \mathrm{R}$ & $\begin{array}{l}t_{\min }(\mathrm{s}) \\
v_{\max }\left(\mathrm{m} \cdot \mathrm{s}^{-1}\right) \\
\tau(\mathrm{s}) \\
\text { Flow behavior }\end{array}$ & $\begin{array}{l}33 \pm 1 \\
0.33 \pm 0.01 \\
54 \pm 2 \\
\text { W.L. }\end{array}$ & $\begin{array}{l}44 \pm 2 \\
0.29 \pm 0.01 \\
56 \pm 2 \\
\text { W.L. }\end{array}$ & $\begin{array}{l}57 \pm 1 \\
0.23 \pm 0.01 \\
72 \pm 2 \\
\text { W.L. }\end{array}$ & $\begin{array}{l}134 \pm 1 \\
0.27 \pm 0.02 \\
178 \pm 2 \\
\text { W.L. }\end{array}$ & $\begin{array}{l}36 \pm 1 \\
0.31 \pm 0.00 \\
55 \pm 1 \\
\text { W.L. }\end{array}$ & $\begin{array}{l}52 \pm 2 \\
0.23 \pm 0.00 \\
62 \pm 2 \\
\text { W.L. }\end{array}$ & $\begin{array}{l}59 \pm 2 \\
0.22 \pm 0.01 \\
73 \pm 1 \\
\text { W.L. }\end{array}$ & $\begin{array}{l}146 \pm 2 \\
0.25 \pm 0.02 \\
186 \pm 1 \\
\text { W.L. }\end{array}$ & $\begin{array}{l}41 \pm 2 \\
0.27 \pm 0.02 \\
67 \pm 2 \\
\text { W.L. }\end{array}$ & $\begin{array}{l}51 \pm 1 \\
0.24 \pm 0.01 \\
74 \pm 2 \\
\text { W.L. }\end{array}$ & $\begin{array}{l}74 \pm 2 \\
0.17 \pm 0.02 \\
95 \pm 2 \\
\text { W.L. }\end{array}$ & $\begin{array}{l}171 \pm 2 \\
0.21 \pm 0.02 \\
229 \pm 2 \\
\text { W.L. }\end{array}$ \\
\hline $2 \mathrm{R}$ & $\begin{array}{l}t_{\min }(\mathrm{s}) \\
v_{\max }\left(\mathrm{m} \cdot \mathrm{s}^{-1}\right) \\
\tau(\mathrm{s}) \\
\text { Flow behavior }\end{array}$ & $\begin{array}{l}33 \pm 1 \\
0.33 \pm 0.01 \\
53 \pm 2 \\
\text { W.L. }\end{array}$ & $\begin{array}{l}43 \pm 1 \\
0.28 \pm 0.01 \\
57 \pm 2 \\
\text { W.L. }\end{array}$ & $\begin{array}{l}57 \pm 2 \\
0.23 \pm 0.01 \\
72 \pm 1 \\
\text { W.L. }\end{array}$ & $\begin{array}{l}133 \pm 2 \\
0.27 \pm 0.02 \\
179 \pm 1 \\
\text { W.L. }\end{array}$ & $\begin{array}{l}36 \pm 2 \\
0.31 \pm 0.00 \\
54 \pm 1 \\
\text { W.L. }\end{array}$ & $\begin{array}{l}52 \pm 1 \\
0.23 \pm 0.00 \\
61 \pm 1 \\
\text { W.L. }\end{array}$ & $\begin{array}{l}59 \pm 1 \\
0.22 \pm 0.01 \\
73 \pm 1 \\
\text { W.L. }\end{array}$ & $\begin{array}{l}145 \pm 1 \\
0.25 \pm 0.02 \\
186 \pm 1 \\
\text { W.L. }\end{array}$ & $\begin{array}{l}42 \pm 1 \\
0.26 \pm 0.01 \\
68 \pm 2 \\
\text { W.L. }\end{array}$ & $\begin{array}{l}50 \pm 1 \\
0.24 \pm 0.02 \\
72 \pm 2 \\
\text { W.L. }\end{array}$ & $\begin{array}{l}75 \pm 1 \\
0.17 \pm 0.02 \\
94 \pm 2 \\
\text { W.L. }\end{array}$ & $\begin{array}{l}175 \pm 2 \\
0.21 \pm 0.02 \\
231 \pm 2 \\
\text { W.L. }\end{array}$ \\
\hline $3 R$ & $\begin{array}{l}t_{\min }(\mathrm{s}) \\
v_{\max }\left(\mathrm{m} \cdot \mathrm{s}^{-1}\right) \\
\tau(\mathrm{s}) \\
\text { Flow behavior }\end{array}$ & $\begin{array}{l}32 \pm 2 \\
0.35 \pm 0.01 \\
51 \pm 2 \\
\text { W.L. }\end{array}$ & $\begin{array}{l}43 \pm 1 \\
0.28 \pm 0.01 \\
58 \pm 1 \\
\text { W.L. }\end{array}$ & $\begin{array}{l}58 \pm 1 \\
0.22 \pm 0.01 \\
71 \pm 2 \\
\text { W.L. }\end{array}$ & $\begin{array}{l}135 \pm 2 \\
0.27 \pm 0.02 \\
179 \pm 1 \\
\text { W.L. }\end{array}$ & $\begin{array}{l}36 \pm 1 \\
0.31 \pm 0.00 \\
55 \pm 1 \\
\text { W.L. }\end{array}$ & $\begin{array}{l}52 \pm 1 \\
0.23 \pm 0.00 \\
63 \pm 2 \\
\text { W.L. }\end{array}$ & $\begin{array}{l}60 \pm 2 \\
0.22 \pm 0.01 \\
\mathbf{7 7 \pm 1} \\
\text { L. }\end{array}$ & $\begin{array}{l}147 \pm 2 \\
0.25 \pm 0.02 \\
196 \pm \mathbf{2} \\
\text { L. }\end{array}$ & $\begin{array}{l}42 \pm 2 \\
0.26 \pm 0.01 \\
69 \pm 2 \\
\text { W.L. }\end{array}$ & $\begin{array}{l}51 \pm 1 \\
0.24 \pm 0.01 \\
75 \pm 2 \\
\text { W.L. }\end{array}$ & $\begin{array}{l}76 \pm 2 \\
0.17 \pm 0.02 \\
106 \pm 1 \\
\text { L. }\end{array}$ & $\begin{array}{l}172 \pm 2 \\
0.21 \pm 0.02 \\
\mathbf{2 4 6} \pm \mathbf{2} \\
\text { L. }\end{array}$ \\
\hline
\end{tabular}

$t_{\min }=$ minimum time; $v_{\max }=$ maximum velocity; $\tau=$ mean residence time; L. = Laminar; W.L. = Wavy-laminar 


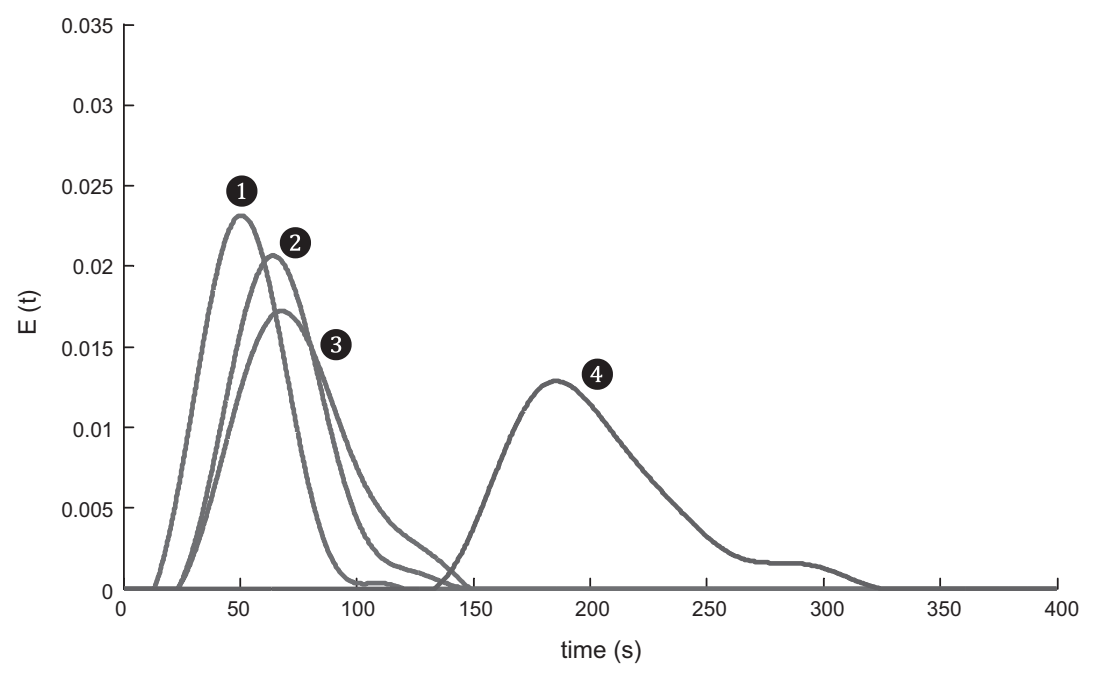

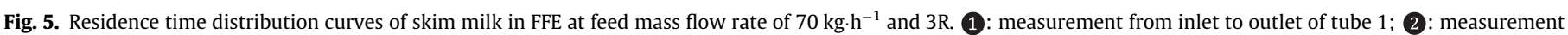

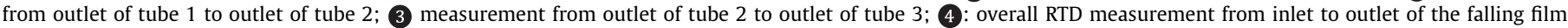
evaporator.

product. Measurement of the mean residence time was not sensitive to detect a decrease in the mean residence time when the evaporation rate decreased very slightly.

It is of note that, one dimensionless number, $R e_{\mathrm{f}}$ was used for determining the flow regime. In this work $R e_{\mathrm{f}}$ described not only the flow regime, but also the mean residence time of the product in the FFE. Where $R e_{\mathrm{f}}<25$, in sections 3 and 4 , in $3 \mathrm{R}$ at $70 \mathrm{~kg} \cdot \mathrm{h}^{-1}$ and $60 \mathrm{~kg} \cdot \mathrm{h}^{-1}$, the flow behavior changed from wavy-laminar to laminar flow and the mean residence time of the product increased from $73 \mathrm{~s}$ to $77 \mathrm{~s}, 186 \mathrm{~s}$ to $196 \mathrm{~s}, 94 \mathrm{~s}$ to $106 \mathrm{~s}$ and $231 \mathrm{~s}$ to $246 \mathrm{~s}$, compared with $2 \mathrm{R}$ in the same section, where $R e_{\mathrm{f}}>25$. In these experiments, to minimize heat treatment (time/temperature), which is an important factor in controlling final product quality, the flow regime of skim milk in FFE should be in the wavy-laminar region, $R e_{\mathrm{f}}>25$. This can be achieved by changing the operational parameters, i.e. mass flow rate, heating power, etc. In a recently work Gourdon et al. (2015) showed that the flow behavior of whole and skim milk in FFE, was affected by total solids contents, flow rates and driving temperature differences.

All experimental RTD curves for Section 4 presented shoulder areas at the end of passage through the FFE. These shoulders were also observed from Section 2 in the $2 \mathrm{R}$ at a feed mass flow rate of $80 \mathrm{~kg} \cdot \mathrm{h}^{-1}$ and $70 \mathrm{~kg} \cdot \mathrm{h}^{-1}$, and from Section 1 in the $2 \mathrm{R}$, at a feed mass flow rate of $60 \mathrm{~kg} \cdot \mathrm{h}^{-1}$.

Fig. 6 shows the models and experimental curves for the $3 R$ of experiments conducted at a feed mass flow rate of $60 \mathrm{~kg} \cdot \mathrm{h}^{-1}$. For modeling the results of RTD, two reactor sets were used in parallel. This model represents two different flows, where a main and minor flow was represented by the reactor set $A$ and $B$, respectively. The parameters used for modeling each reactor set and the standard deviation between model and experimental RTD for all sections, runs and feed mass flow rates are presented in Table 4.

The accuracy and reproducibility of the model was satisfactory, considering the very low standard deviations obtained (Table 4).

In this model, $E_{\mathrm{a}}(t)$ describes the path of between $94.0 \%$ and $99.9 \%$ of product fluid elements. $N_{\mathrm{a}}$ could therefore be used to describe the dispersion in the residence time of the skim milk in FFE. A more highly concentrated product required a smaller number of tanks in series, corresponding to greater dispersion of the product. Among the 27 skim milk concentrations studied, the product with the lowest concentration, located at the bottom of T1/1R at $80 \mathrm{~kg} \cdot \mathrm{h}^{-1}$, had a value of $N_{\mathrm{a}}=14$. This value decreased when the product was concentrated. The value of the product with greater concentration at the bottom of T3/3R at $60 \mathrm{~kg} \cdot \mathrm{h}^{-1}$, was $N_{\mathrm{a}}=6$. Function $E_{\mathrm{b}}(t)$, described a small fraction of the fluid elements and served to explain the shoulder curves in the experimental RTD functions (Figs. 6 and 7).

When the shoulders in the RTD curves did not occur, $99.9 \%$ of the product fluid elements passed through reactor set $\mathrm{A}$, and the values of $\tau_{\mathrm{i}}$ and $N_{\mathrm{i}}$ were the same for both reactor sets. From the moment that the shoulders were observed, the product fluid elements going to reactor set A decreased and $N_{\mathrm{b}}$ and $\tau_{\mathrm{b}}$ increased, showing an increase in the fluid elements that passed through reactor set B. These fluid elements represented $0.9-7 \%$ of total skim milk fluid elements that entered the evaporator. At a feed mass flow rate of $80 \mathrm{~kg} \cdot \mathrm{h}^{-1}$, the fluid elements that passed through reactor set A decreased from $99.1 \%$ to $96.0 \%$ at T1/R2 and T3/R3, respectively. For section 3 at T3/R3, 4.0\%, 4.5\% and 5.0\% of fluid elements passed through reactor set $\mathrm{B}$ for the feed mass flow rates of $80 \mathrm{~kg} \cdot \mathrm{h}^{-1}, 70 \mathrm{~kg} \cdot \mathrm{h}^{-1}$ and $60 \mathrm{~kg} \cdot \mathrm{h}^{-1}$, respectively.

In section (4) the shoulders were always present in the RTD curves, even if they were not present in the RTD curves of previously sections. It may be due to sensitivity of the model to detecting a small quantity of the fluid elements passing through reactor set B. The quantity of product passing through reactor set A decreased from $96 \%$ to $92.5 \%$ for Section 4, at T3/R3 at feed mass flow rates of $80 \mathrm{~kg} \cdot \mathrm{h}^{-1}$ and $60 \mathrm{~kg} \cdot \mathrm{h}^{-1}$ respectively. Comparison of different sections showed that the fluid elements going to reactor set $A$ decreased when the product concentration increased, and thus an increase in the shoulders at the end of RTD curves was observed.

As mentioned before, the model used in this study takes into account a main and a minor flow. For the experiments when the shoulders in the RTD curves were noted, the minor flow should be considerated as a retarded flow (Fig. 7), due to the high mean residence time presented. These two different flows possibly flow in two layers:

- One representing a small proportion of the fluid elements, demonstrated by reactor set $\mathrm{B}$, where the layer of product flows in contact with the walls of the evaporation tubes; and

- One layer flowing over the first, in the center of the evaporation tubes, representing a greater proportion of the product fluid elements, demonstrated by reactor set $\mathrm{A}$. 

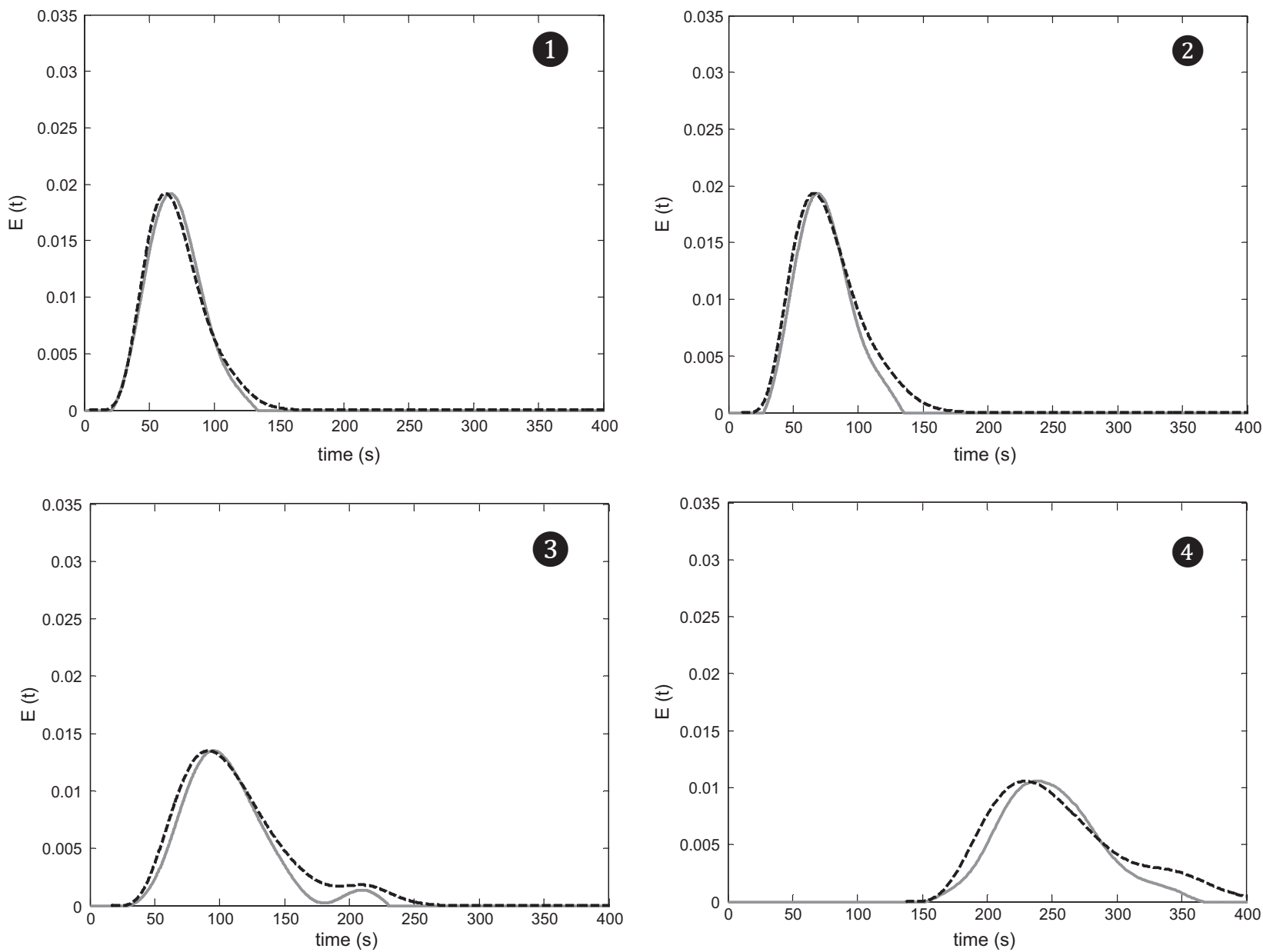

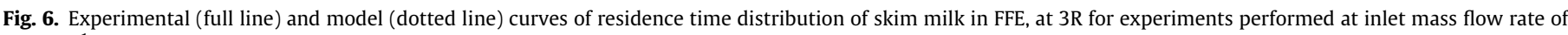

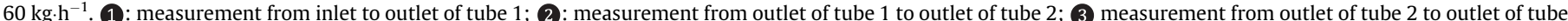

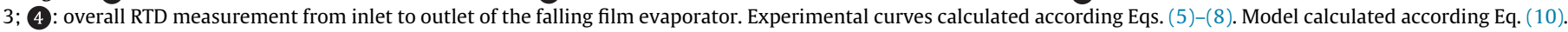

Table 4

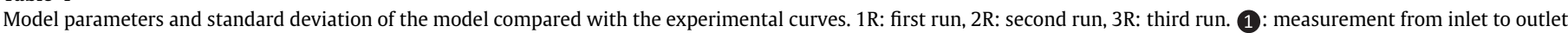

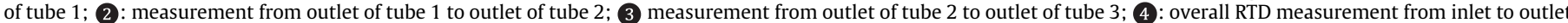
of the falling film evaporator.

\begin{tabular}{|c|c|c|c|c|c|c|c|c|c|c|c|c|c|}
\hline \multirow{2}{*}{\multicolumn{2}{|c|}{$\begin{array}{l}\text { Feed mass flow rate } \\
\text { Section (Fig. 2) }\end{array}$}} & \multicolumn{4}{|c|}{$80 \mathrm{~kg} \cdot \mathrm{h}^{-1}$} & \multicolumn{4}{|c|}{$70 \mathrm{~kg} \cdot \mathrm{h}^{-1}$} & \multicolumn{4}{|c|}{$60 \mathrm{~kg} \cdot \mathrm{h}^{-1}$} \\
\hline & & \multirow{2}{*}{$\begin{array}{l}1 \\
0.999\end{array}$} & \multirow{2}{*}{$\frac{2}{0.999}$} & \multirow{2}{*}{$\begin{array}{l}3 \\
0.999\end{array}$} & \multirow{2}{*}{$\begin{array}{l}4 \\
0.960\end{array}$} & \multirow{2}{*}{$\begin{array}{l}1 \\
0.999\end{array}$} & \multirow{2}{*}{$\begin{array}{l}2 \\
0.999\end{array}$} & \multirow{2}{*}{$\frac{3}{0.999}$} & \multirow{2}{*}{$\begin{array}{l}4 \\
0.945\end{array}$} & \multirow{2}{*}{$\frac{1}{0.999}$} & \multirow{2}{*}{$\frac{2}{0.999}$} & \multirow{2}{*}{$\begin{array}{l}3 \\
0.999\end{array}$} & \multirow{2}{*}{$\frac{4}{0.930}$} \\
\hline $1 \mathrm{R}$ & $a$ & & & & & & & & & & & & \\
\hline & $\tau_{\mathrm{a}}$ & 50 & 47 & 58 & 60 & 51 & 53 & 59 & 60 & 57 & 65 & 79 & 91 \\
\hline & $\tau_{\mathrm{b}}$ & 50 & 47 & 58 & 120 & 51 & 53 & 59 & 145 & 57 & 65 & 79 & 199 \\
\hline & $N_{\mathrm{a}}$ & 14 & 14 & 11 & 10 & 14 & 13 & 11 & 5 & 11 & 11 & 10 & 8 \\
\hline & $N_{\mathrm{b}}$ & 14 & 14 & 11 & 80 & 14 & 13 & 11 & 80 & 11 & 11 & 10 & 60 \\
\hline & Standard deviation & 0.002 & 0.006 & 0.008 & 0.014 & 0.004 & 0.005 & 0.006 & 0.012 & 0.003 & 0.003 & 0.006 & 0.009 \\
\hline \multirow[t]{6}{*}{$2 \mathrm{R}$} & $a$ & 0.999 & 0.991 & 0.990 & 0.955 & 0.999 & 0.950 & 0.980 & 0.940 & 0.975 & 0.975 & 0.975 & 0.927 \\
\hline & $\tau_{\mathrm{a}}$ & 49 & 50 & 59 & 75 & 50 & 53 & 59 & 63 & 61 & 63 & 77 & 92 \\
\hline & $\tau_{\mathrm{b}}$ & 49 & 50 & 104 & 175 & 50 & 98 & 100 & 181 & 123 & 113 & 137 & 208 \\
\hline & $N_{\mathrm{a}}$ & 13 & 11 & 10 & 9 & 13 & 11 & 10 & 5 & 10 & 8 & 9 & 7 \\
\hline & $N_{\mathrm{b}}$ & 13 & 90 & 60 & 110 & 13 & 85 & 60 & 40 & 110 & 80 & 100 & 115 \\
\hline & Standard deviation & 0.002 & 0.004 & 0.006 & 0.010 & 0.003 & 0.003 & 0.005 & 0.009 & 0.002 & 0.003 & 0.005 & 0.008 \\
\hline \multirow[t]{6}{*}{$3 R$} & $a$ & 0.980 & 0.980 & 0.960 & 0.950 & 0.980 & 0.960 & 0.955 & 0.937 & 0.975 & 0.960 & 0.950 & 0.925 \\
\hline & $\tau_{\mathrm{a}}$ & 51 & 51 & 57 & 69 & 51 & 61 & 61 & 71 & 66 & 65 & 89 & 111 \\
\hline & $\tau_{\mathrm{b}}$ & 97 & 97 & 109 & 159 & 101 & 101 & 116 & 169 & 113 & 115 & 199 & 214 \\
\hline & $N_{\mathrm{a}}$ & 12 & 11 & 10 & 8 & 11 & 10 & 7 & 5 & 9 & 7 & 6 & 6 \\
\hline & $N_{\mathrm{b}}$ & 100 & 100 & 100 & 40 & 110 & 30 & 80 & 100 & 80 & 50 & 117 & 70 \\
\hline & Standard deviation & 0.002 & 0.004 & 0.006 & 0.012 & 0.002 & 0.003 & 0.004 & 0.010 & 0.002 & 0.005 & 0.003 & 0.008 \\
\hline
\end{tabular}

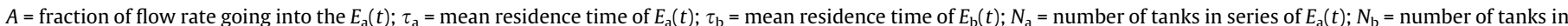
series of $E_{\mathrm{b}}(t)$. 


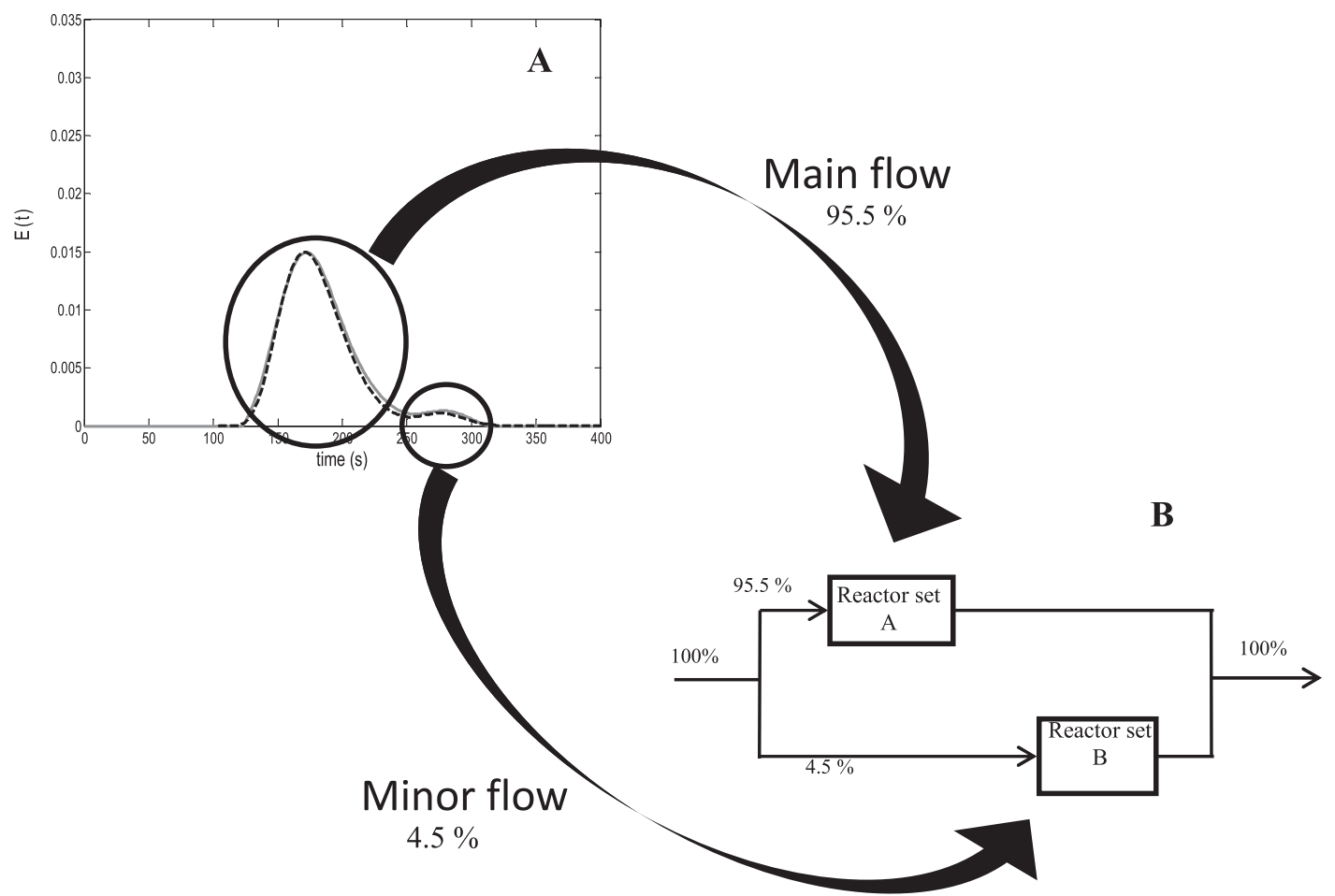

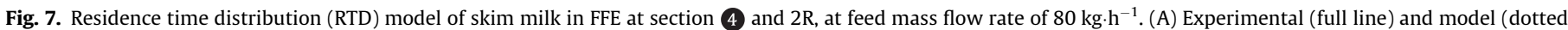

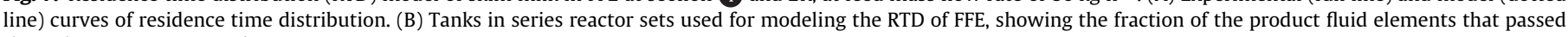
through reactor sets $\mathrm{A}$ and $\mathrm{B}$.

Increased viscosity in the FFE results in increased film thickness (Gray, 1981), that could be caused by an increase in the flowing fluid elements in contact with the surface of the evaporation tubes. This layer would be decelerated by friction forces, surface tension, viscosity, etc. and thus present a longer residence time. On the other hand, the majority of the product may flow in a superimposed layer, where the above deceleration forces have a minor influence, thus contributing to a higher flow velocity and shorter residence time.

\section{Conclusion}

The $R e_{\mathrm{f}}$ provided information about the mean residence time of the skim milk flow in the FFE. The mean residence time of the product was higher when the flow regime was characterized as laminar flow. The flow velocity in wavy-laminar conditions was higher than in laminar conditions.

The RTD approach provided greater understanding of the flow in FFE. The concentration affected the dispersion of flow in the FFE but not the time required for the first particles to exit from the evaporator: the more concentrated the product, the greater the dispersion of its particles. The change in $t_{\min }$ was affected by the mass flow rate and section (distance covered by the product).

Some RTD curves exhibited shoulders at the ends. This phenomenon characterized part of the product that followed another path in the FFE, classified as two different flows, a main and a minor flow, where two layers of product flowed through the evaporation tubes. One, represented by reactor set $\mathrm{B}$, and flowing in contact with the inner surface of the tube, had a longer mean residence time, and the second, demonstrated by reactor set $\mathrm{A}$ and representing the greater fraction of product, and flowed over the first layer, and had a shorter mean residence time compared to the first layer.

The model with two reactor sets in parallel was effective in modeling the RTD curves. This model allowed calculation of the amount of product that took different paths in the FFE, and helped to improve understanding of the flow of skim milk in FFE.

The future of this work involves combining the RTD approach with different products and operating conditions in the evaporator. These parameters can be accessed either by modeling or by measurement, and will make it possible to describe the time/temperature history of the product, and to establish further correlations with changes in constituents and operating parameters.

\section{References}

Baldwin, A., Baucke, A., Sanderson, W., 1980. The effect of concentrate viscosity on the properties of spray-dried skim milk powder. N. Z. J. Dairy Sci. Technol. 15, 289-297.

Baloh, A., 1979. Energy in evaporation and drying operations. Zuckerindustrie 104 943-944.

Bimbenet, J.-J., Duquenoy, A., Trystram, G., 2007. Génie des procédés alimentaires, second ed. Technique et Ingénierie, Dunod.

Bird, R.B., Stewart, W.E., Lightfoot, E.N., 1960. Transport Phenomena. New York

Bouman, S., Waalewijn, R., Dejong, P., Vanderlinden, H., 1993. Design of falling-film evaporators in the dairy-industry. J. Soc. Dairy Technol. 46, 100-106.

Burton, H., Franklin, J.G., Williams, D.J., Chapman, H.R., Jean, A., Harrison, W., Clegg, L.F.L., 1959. An analysis of the performance of an ultra-high-temperature milk sterilizing plant: IV. Comparison of experimental and calculated sporicidal effects for a strain of Bacillus stearothermophilus. J. Dairy Res. 26, 221-226. http://dx.doi.org/10.1017/S002202990000995X.

Chong, L.X.Q., Lin, S.X.Q., Chen, X.D., 2009. Concentration dependent viscosity in milk evaporation process. 25. pp. 1149-1158.

Chun, M., Park, S., 1995. Effects of turbulence model and interfacial shear on heattransfer in turbulent falling liquid-films. Int. Commun. Heat Mass Transf. 22, 112. http://dx.doi.org/10.1016/0735-1933(94)00047-0.

Chun, K.R., Seban, R.A., 1971. Heat transfer to evaporating liquid films. J. Heat Transf. 93, 391. http://dx.doi.org/10.1115/1.3449836.

Danckwerts, P.V., 1953. Continuous flow systems. distribution of residence times. Chem. Eng. Sci. Front. Chem. Eng. Sci. 2, 1-13. http://dx.doi.org/10.1016/00092509(96)81810-0.

Ducept, F., Sionneau, M., Vasseur, J., 2002. Superheated steam dryer: simulations and experiments on product drying. Chem. Eng. J. 86, 75-83. http://dx.doi.org/ 10.1016/S1385-8947(01)00275-3.

Gänzle, M.G., Haase, G., Jelen, P., 2008. Lactose: crystallization, hydrolysis and value-added derivatives. Int. Dairy J. 18, 685-694. http://dx.doi.org/10.1016/ j.idairyj.2008.03.003. 
Gourdon, M., Innings, F., Jongsma, A., Vamling, L., 2015. Qualitative investigation of the flow behaviour during falling film evaporation of a dairy product. Exp. Therm. Fluid Sci. 60, 9-19. http://dx.doi.org/10.1016/j.expthermflusci.2014.07.017.

Gray, R.M., 1981. Subject: "Skim milk" technology of skimmed milk evaporation. Int. J. Dairy Technol. 34, 53-57. http://dx.doi.org/10.1111/j.1471-0307.1981. tb01499.x.

Gutierrez, C.G.C.C., Dias, E.F.T.S., Gut, J.A.W., 2010. Residence time distribution in holding tubes using generalized convection model and numerical convolution for non-ideal tracer detection. J. Food Eng. 98, 248-256. http://dx.doi.org/ 10.1016/j.jfoodeng.2010.01.004.

Jeantet, R., Ducept, F., Dolivet, A., Méjean, S., Schuck, P., 2008. Residence time distribution: a tool to improve spray-drying control. Dairy Sci. Technol. 88, 31-43. http://dx.doi.org/10.1051/dst:2007006.

Jebson, R.S., Chen, H., 1997. Performances of falling film evaporators on whole milk and a comparison with performance on skim milk. J. Dairy Res. 64, 57-67. http://dx.doi.org/10.1017/S0022029996001963.

Jebson, R., Iyer, M., 1991. Performances of falling film evaporators. J. Dairy Res. 58, 29-38.

Li, W., Wu, X.-Y., Luo, Z., Webb, R.L., 2011. Falling water film evaporation on newlydesigned enhanced tube bundles. Int. J. Heat Mass Transf. 54, 2990-2997. http://dx.doi.org/10.1016/j.ijheatmasstransfer.2011.02.052.

Mafart, P., 1991. Génie Industriel Alimentaire. Lavoisier, Paris, France.

Malcata, F., 1991. Modeling of a series of continuously stirred tank reactors for thermal-processing of liquid foods. Int. J. Food Sci. Technol. 26, 535-546.

Morison, K.R., Broome, S.R., 2014. Upward vapour flows in falling film evaporators and implications for distributor design. Chem. Eng. Sci. 114, 1-8. http:// dx.doi.org/10.1016/j.ces.2014.04.015.

Pehlivan, H., Ozdemir, M., 2012. Experimental and theoretical investigations of falling film evaporation. Heat Mass Transf. 48, 1071-1079. http://dx.doi.org/ 10.1007/s00231-011-0962-x.
Prost, J.S., González, M.T., Urbicain, M.J., 2006. Determination and correlation of heat transfer coefficients in a falling film evaporator. J. Food Eng. 73, 320-326. http://dx.doi.org/10.1016/j.jfoodeng.2005.01.032.

Schuck, P., 2002. Spray drying of dairy products: state of the art. Lait $82,375-382$. http://dx.doi.org/10.1051/lait:2002017.

Sharifi, M., Young, B., 2012. Milk total solids and fat content soft sensing via electrical resistance tomography and temperature measurement. Food Bioprod. Process. 90, 659-666. http://dx.doi.org/10.1016/j.fbp.2012.05.001.

Silveira, A.C.P., Carvalho, A.F., Perrone, İ.T., Fromont, L., Méjean, S., Tanguy, G., Jeantet, R., Schuck, P., 2013. Pilot-scale investigation of effectiveness of evaporation of skim milk compared to water. Dairy Sci. Technol. 93, 537-549. http://dx.doi.org/10.1007/s13594-013-0138-1.

Steffe, J.F., 1996. Rheological Methods in Food Process Engineering, second ed. Freeman Press, East Lansing, USA.

Thor, W., Loncin, M., 1978. Optimisation du rinçage final après nettoyage et désinfection. I.A.A. Industrie Alimentaire Agricole 95, 1095-1100.

Verdurmen, R.E.M., Straatsma, H., Verschueren, M., van Haren, J.J., Smit, E., Bargeman, G., de Jong, P., 2002. Modelling spray drying processes for dairy products. Lait 82, 453-463. http://dx.doi.org/10.1051/lait:2002023.

Villermaux, J., 1982. Chemical reactors. Recherche 13, 868-879.

Westergaard, V., 2004. Milk Powder Technology Evaporation and Spray Drying. Niro A/S, Copenhagen, Denmark.

Zhu, P., Mejean, S., Blanchard, E., Jeantet, R., Schuck, P., 2011. Prediction of dry mass glass transition temperature and the spray drying behaviour of a concentrate using a desorption method. J. Food Eng. 105, 460-467. http://dx.doi.org/ 10.1016/j.jfoodeng.2011.03.003. 